\title{
Anomalous Property of Liquid Alloys at Temperatures close to the Freezing Point of Pure Component Metal*
}

\author{
By Kazuhisa Okajima, ${ }^{* *}$ Akira Noda*** and Hiroshi Sakao**
}

\begin{abstract}
The present study was performed in an attempt to clarify the anomalous behavior occurring at temperatures close to the freezing point of a component metal in several liquid alloys by employing the emf technique.

By measuring emfs for liquid $\mathrm{Pb}-\mathrm{Hg}, \mathrm{Pb}-\mathrm{Sb}$ and $\mathrm{Zn}-\mathrm{Sb}$ alloys at slowly decreasing temperatures, $\mathrm{E}$ $\mathrm{E}$ zones indicated by two breaks in the emf-temperature relationship were determined.

Good similarity was observed between the compositional dependence of the E E zone and excess stability.
\end{abstract}

(Received November 25, 1987) Keywords: anomalous property, liquid alloy, electromotive force method, E E zone, excess
stability

\section{Introduction}

The emf and density data reported previously $^{(1)-(5)}$ have given evidence in support of the assumption that physical anomalies occur in liquid alloys. The present study was performed with the purpose of clarifying in detail more anomalous behavior at temperatures close to the freezing point of the component metal for liquid $\mathrm{Pb}-\mathrm{Hg}, \mathrm{Pb}-\mathrm{Sb}$ and $\mathrm{Zn}-\mathrm{Sb}$ alloys by employing the emf technique. The emf technique is quite precise and will easily permit observations of small changes in the emf-temperature relationship.

Important findings on the structural changes at comparatively low temperatures of the liquid alloys was obtained from the present study and are reported below.

\section{Experimental Method}

The experiments with the $\mathrm{Pb}-\mathrm{Hg}$ alloys were performed under a protective atmosphere of

* This paper was presented at the Spring Meeting of the Japan Institute of Metals, held in Tokyo on April 3, 1986.

** Department of Metallurgy, Faculty of Engineering, Nagoya University, Nagoya 464, Japan.

*** Graduate Student, Nagoya University, Nagoya. Present address: Hitachi Metals Ltd., Kitakyushu 808, Japan. flowing argon gas as shown in Fig. 1 (A), in view of the high vapor pressure of mercury. The experimental procedures for the other two systems were essentially the same as in the previous paper ${ }^{(2)(3)}$ and the cell design employed is illustrated in Fig. 1 (B).

Metals of 99.9 to $99.9999 \%$ purities and iodides and chlorides of high purity commercial grade were used.

The following three kinds of concentration cells were constructed to measure the emfs in each temperature range.

$$
\begin{array}{r}
\mathrm{Pb}(1 \text { or } \mathrm{s})\left|\mathrm{KI}-\mathrm{CdI}_{2}-\mathrm{PbI}_{2}(1)\right| \mathrm{Pb}-\mathrm{Hg}(1), \\
500 \sim 635 \mathrm{~K} \\
\mathrm{~Pb}(\mathrm{l})\left|\mathrm{KCl}-\mathrm{LiCl}-\mathrm{PbCl}_{2}(1)\right| \mathrm{Pb}-\mathrm{Sb}(1), \\
810 \sim 1020 \mathrm{~K} \\
\mathrm{Zn}(1)\left|\mathrm{KCl}-\mathrm{LiCl}-\mathrm{ZnCl}_{2}(1)\right| \mathrm{Zn}-\mathrm{Sb}(1), \\
790 \sim 1020 \mathrm{~K} .
\end{array}
$$

The electrolytes were molten $\mathrm{KI}-\mathrm{CdI}_{2}$ salts with $N_{\mathrm{CaI}_{2}}=0.52$ and $\mathrm{KCl}-\mathrm{LiCl}$ eutectic chlorides containing $\mathrm{PbI}_{2}, \mathrm{PbCl}_{2}$ and $\mathrm{ZnCl}_{2}$ of several mole percent, respectively.

The experimental procedure for the $\mathrm{Pb}-\mathrm{Hg}$ alloys was as follows: the concentration cell was constructed in a nichrome-wire wound vertical furnace. The electrolyte and the alloy were homogenized by shaking and agitation as has been described previously ${ }^{(2)}$. The atmosphere was argon gas flowing through the 


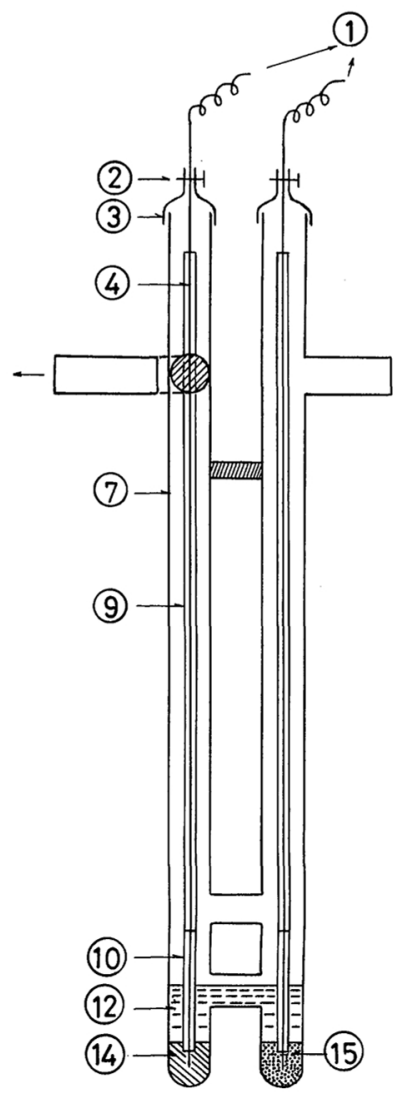

(A)

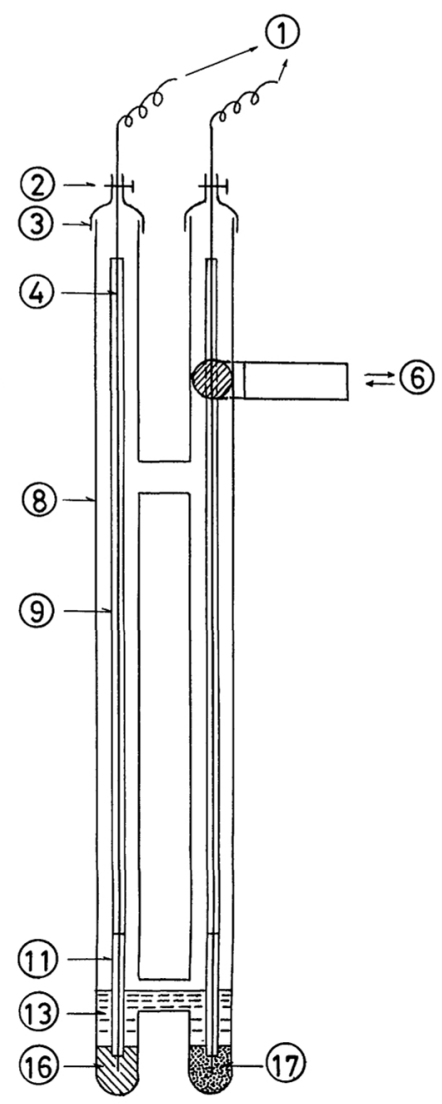

(B)

Fig. 1 Cells for emf measurements.

(1) Potentiometer
(2) Pinch cock
(3) Vinyl tube
(4) Tungsten lead
(5) Ar gas
(6) Vacuum or Ar gas
(7) Hard glass
(8) Quartz
(9) Porcelain sheath

(10) Hard glass insulator

(11) Quartz insulator

(12) Electrolyte, $\mathrm{KI}-\mathrm{CdI}_{2}-\mathrm{PbI}_{2}$

(13) Electrolyte, liquid chlorides

(14) Pure liquid or solid lead

(15) Liquid $\mathrm{Pb}-\mathrm{Hg}$ alloy

(16) Pure liquid metal

(17) Liquid alloy cell tubes. After the argon atmosphere was established the gas flow was decreased as much as possible to ensure silent flow. The temperature was raised to about $630 \mathrm{~K}$ and the cell was maintained for $5.4 \mathrm{ks}$ at this temperature. Then, the emf measurements were performed at continuously decreasing temperatures by employing a potentiometer.

In the cases of cells (2) and (3), the electrolyte was melted and then dehydrated by evacuation for about $1.2 \mathrm{ks}$ at a certain temperature. In the experiments with the $\mathrm{Pb}-\mathrm{Sb}$ alloys, for example, lead and antimony accurately weighed out in the desired proportion, were introduced into the alloy electrode tube in small amounts alternately at a temperature higher than $100 \mathrm{~K}$ above the liquidus temperature. The alloy was agitated thoroughly with a quartz rod. After the cell was maintained for $5.4 \mathrm{ks}$ near the starting temperature ${ }^{(3)}$, the emf 
measurements were performed at decreasing temperatures, the cooling rate being about $0.025 \mathrm{Ks}^{-1}$.

\section{Experimental Results}

\section{Experimental results on the $\mathbf{E} \mathbf{E}$ zone of the less noble component}

Examples of this type are the $\mathrm{Pb}-\mathrm{Hg}$ and $\mathrm{Pb}-\mathrm{Bi}$ systems. Detailed results for the $\mathrm{Pb}-\mathrm{Bi}$ system will be described subsequently ${ }^{(6)}$ in connection with the density behavior. The $\mathrm{E} E$ zone was determined starting from the fact that the emf-temperature curves in the $\mathrm{Pb}-\mathrm{Hg}$ alloys broke distinctly at temperatures close to the freezing point of lead. For this reason, the experiments with the $\mathrm{Pb}-\mathrm{Hg}$ alloys will be described first.

Although activity measurements of $\mathrm{Pb}-\mathrm{Hg}$ alloys by the emf method have been carried out at narrow temperature ranges below $500 \mathrm{~K}^{(7)}$, no literature values above this temperature are available except for vapor pressure measurements ${ }^{(8)}$. Consequently, the present study would also be of interest from the standpoint of determination of activities.

The emf measurements were carried out in the temperature range between $635 \mathrm{~K}$, which depends on the boiling temperature of mercury, and $500 \mathrm{~K}$. Since the emf $E_{\mathrm{s}}$ measured below the freezing point of lead by cell (1) was the value relative to the standard of pure solid lead, the value was converted into the emf $E_{1}$ of liquid lead by employing the free energy of fusion for lead ${ }^{(9)}$.

$$
\begin{aligned}
& \mathrm{Pb}(\mathrm{s})=\mathrm{Pb}(\mathrm{l}) \\
& \begin{aligned}
\Delta G^{\circ}= & 1805-20.43 T \log T+6.43 \times 10^{-3} T^{2} \\
& +49.89 T \\
E_{\mathrm{l}}=E_{\mathrm{s}} & +\Delta G^{\circ} / n F
\end{aligned}
\end{aligned}
$$

where $E_{1}$ and $E_{s}$ are the emf values relative to the standards of pure liquid and solid lead and $n$ and $F$ are the valence of ion and the Faraday constant, respectively.

Figure 2 illustrates the emf values relative to pure liquid lead calculated from the measured emfs. Some data between 600 and $585 \mathrm{~K}$ are excluded because these are affected by the solidification heat of pure lead. Pronounced breaks in the emf-temperature relationship observed at temperatures close to the freezing point of lead lead to the determination of the $E$ E zone. For example, the data at $N_{\mathrm{Pb}}=0.900$ showed a pronounced break at $610 \mathrm{~K}$ though the alloy was in the liquid state near this temperature. The partial molar entropy of mixing can be determined from the emf-temperature relationship. Thus, such behavior is suggestive of some structural change in the liquid alloy.

The breaking points at varied compositions are joined by broken lines. For convenience of illustration, the broken line at the high temperature side is drawn on the basis of the $\mathrm{E} E$ zone width of about $25 \mathrm{~K}$. This zone is now termed the "zone of elemental effect" or "E E zone".

As for additional evidence of such a breaking characteristic, there exist the emf data measured below $500 \mathrm{~K}$ by Yamada et al. ${ }^{(7)}$ The values relative to liquid pure lead calculated from their data are shown in Fig. 2. It is noteworthy that Yamada's data are characterized by the two breaks each close to $430 \mathrm{~K}$ similar to the present data at higher temperatures. For a better understanding of this breaking characteristic, straight broken lines are drawn through the ranges between the two breaking points and are extended over these ranges as shown at $N_{\mathrm{Pb}}=0.100$ and 0.0102 . The situation is the same in the other data which will be described subsequently. Although not shown in Fig. 2, Yamada's data for a range of $N_{\mathrm{Pb}}=0.0102 \sim 0.000364$ can also give a similar curve. The agreement between the data of the present study and Yamada et al. may be gathered to some extent from a comparison between both data at / near $N_{\mathrm{Pb}}=0.401$ and 0.539. It is evident from Fig. 12 that the breaks observed in the present study are due to the pre-freezing anomaly of pure lead, while those of Yamada et al. may be attributed to the compound $\mathrm{HgPb}_{2}$ though there is an uncertainty with regard to the formation of this compound. The horizontal region $\mathrm{R}$ in the emf-temperature relationships lying between 464 and $506 \mathrm{~K}$ was assumed by tying the present results with the data of Yamada et al. because of the difficulty of measurement over most of this range. It may be generally expected that the 


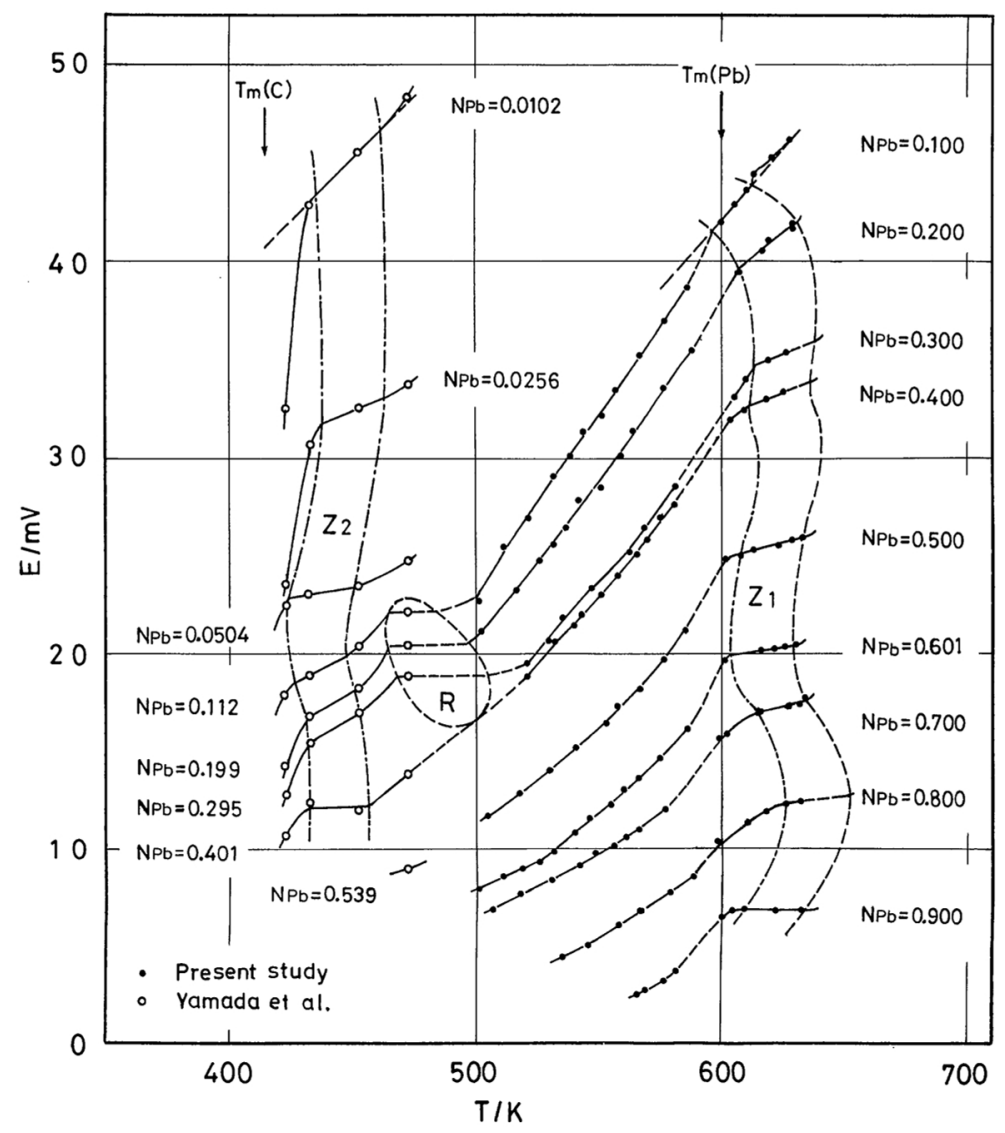

Fig. 2 Relationship between emf and temperature of liquid $\mathrm{Pb}-\mathrm{Hg}$ alloys. $T_{\mathrm{m}}(\mathrm{Pb})$ : Melting point of lead, $T_{\mathrm{m}}(\mathrm{C})$ : Incongruent melting point of compound, $Z_{1}: \mathrm{E} \mathrm{E}$ zone, $Z_{2}$ : Zone of compound effect.

horizontal trend in the emf-temperature relationship corresponds nearly to the leveling trend of the activity curve. Thus the flat trends of the activity curves shown in Fig. 3 suggest the existence of the $\mathrm{R}$ region. Similar trends have frequently been noted in the previous papers $^{(1)(5)(10)}$.

This important finding that the emf-temperature breaks occur at temperatures close to the freezing point of the component metal, will be extended further for other alloy systems. For the purpose of knowing whether such measurements are possible, Table 1 classifies the phase diagrams ${ }^{(11)-(13)}$ into eight types.

Measurements above $1073 \mathrm{~K}$ are difficult to perform so as to distinguish a small break because of the high temperature. Also, below
$573 \mathrm{~K}$, the measurements are troublesome in the selection of the electrolyte. Systems in which the anomaly can be measured simply by employing an electrochemical cell with a standard electrode of pure liquid metal are, suprisingly, limited to only three out of a total of 805 different systems. Because the $\mathrm{Pb}-\mathrm{Sb}$ and $\mathrm{Zn}$-Sb systems belong to this type, studies of these systems are very valuable. In the $\mathrm{Pb}$ $\mathrm{Hg}$ and $\mathrm{Pb}-\mathrm{Bi}$ systems belonging to type VII, special techniques must be employed. Among the measurable systems, the $\mathrm{Pb}-\mathrm{Sb}$ and $\mathrm{Zn}-\mathrm{Sb}$ systems are reported in the present paper and the $\mathrm{Pb}-\mathrm{Bi}$ system will be reported separately. 


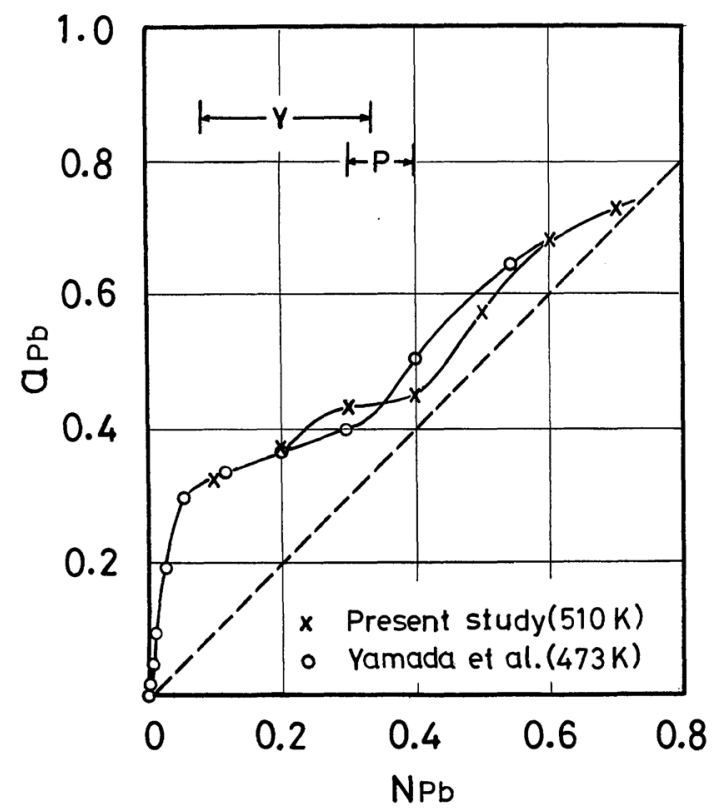

Fig. 3 Activities of component lead in liquid $\mathrm{Pb}-\mathrm{Hg}$ alloys. P: Flat trend of the activity curve in the present study, Y: Flat trend of the activity curve by Yamada et al.

\section{Experimental results on the $\mathbf{E} \mathbf{E}$ zone of the noble component}

Since phase rule consideration shows that the thermodynamic properties of two components of an alloy are interdependent, the existence of the $\mathrm{E} \mathrm{E}$ zone could also be expected for the noble component while the component to measure the emf is less noble ${ }^{(14)}$. Measurements of this kind are very important because the number of systems in which measurements are possible, is very small as shown in Table 1 -i.e. Type VIII, in which the component B correspoinds to the noble one.

Figures 4 and 5 show the experimental results for the $\mathrm{Pb}$-Sb alloys. Although the extents of the breaks are small generally in the eutectic system, the information obtained is important as described above. However, since the curves close to the $\mathrm{E} \mathrm{E}$ zone boundaries of the emf-temperature relationships as shown at $N_{\mathrm{Pb}}=0.100,0.200$ and 0.750 etc. are forming with a consistent trend, such a curve

Table 1 Classification of binary alloy systems according to the possibility of measurement of $\mathrm{E} E$ zones.

\begin{tabular}{|c|c|c|c|c|c|}
\hline & Type & Examples & $\begin{array}{l}\text { Number of } \\
\text { systems }\end{array}$ & Percentage & $\begin{array}{l}\text { Possibility of } \\
\text { measurement }\end{array}$ \\
\hline I & $T_{\mathrm{m}}^{\mathrm{A}}$ and / or $T_{\mathrm{m}}^{\mathrm{B}}$ are higher than $1073 \mathrm{~K}$ & $\mathrm{Ag}-\mathrm{Cu}, \mathrm{Fe}-\mathrm{Mn}$ & 638 & 79 & Almost impossible \\
\hline II & $T_{\mathrm{m}}^{\mathrm{A}}$ and $T_{\mathrm{m}}^{\mathrm{B}}$ are lower than $573 \mathrm{~K}$ & $\mathrm{Ga}-\mathrm{In}, \mathrm{K}-\mathrm{Cs}$ & 17 & 2.1 & Probably impossible \\
\hline III & $\begin{array}{l}\text { System forming compound of higher } \\
\text { melting point }\end{array}$ & $\mathrm{Bi}-\mathrm{Mg}, \mathrm{Ga}-\mathrm{Sb}$ & 78 & 10 & Almost impossible \\
\hline IV & Two-liquid phase system & $\mathrm{Al}-\mathrm{Cd}, \mathrm{Bi}-\mathrm{Zn}$ & 23 & 2.8 & Impossible \\
\hline V & System of $T_{\mathrm{m}}^{\mathrm{A}} \fallingdotseq T_{\mathrm{m}}^{\mathrm{B}}$ & $\mathrm{Al}-\mathrm{Mg}, \mathrm{Cd}-\mathrm{Pb}$ & 4 & 0.5 & Impossible \\
\hline VI & $\begin{array}{l}\text { System having no suitable } \\
\text { electrolyte etc. }\end{array}$ & $\mathrm{Te}-\mathrm{S}, \mathrm{Ce}-\mathrm{Pu}$ & 12 & 1.5 & Probably impossible \\
\hline VII & $T_{\mathrm{m}}^{\mathrm{A}}>T_{\mathrm{m}}^{\mathrm{B}}$, Cell $\mathrm{A}(\mathrm{l})\left|\mathrm{A}^{+x}\right| \mathrm{A}-\mathrm{B}(\mathrm{l})$ & $\mathrm{Pb}-\mathrm{Hg}, \mathrm{Pb}-\mathrm{Bi}$ & 30 & 3.7 & $\begin{array}{l}\text { Impossible without } \\
\text { special technique }\end{array}$ \\
\hline VIII & $T_{\mathrm{m}}^{\mathrm{A}}<T_{\mathrm{m}}^{\mathrm{B}}$, Cell $\mathrm{A}(\mathrm{l})\left|\mathrm{A}^{+x}\right| \mathrm{A}-\mathrm{B}(\mathrm{l})$ & $\mathrm{Pb}-\mathrm{Sb}, \mathrm{Zn}-\mathrm{Sb}$ & 3 & 0.4 & Possible \\
\hline
\end{tabular}

$\mathrm{R}_{\mathrm{m}}$ : Schematic region to be measured experimentally.

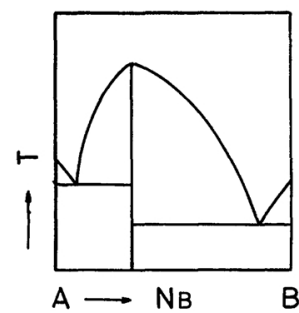

(III)

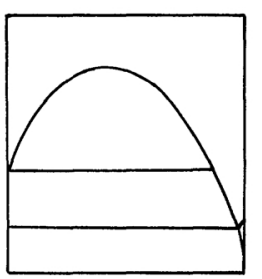

B A

(IV)

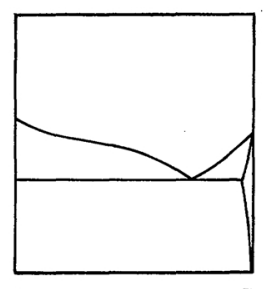

B A

(v)

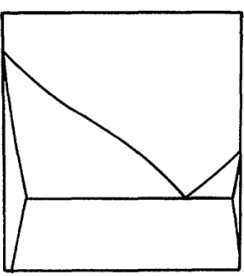

B A

(VII)

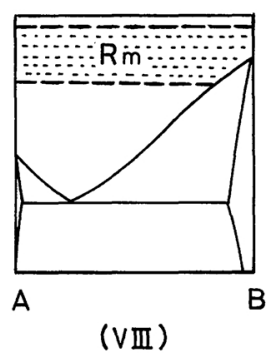




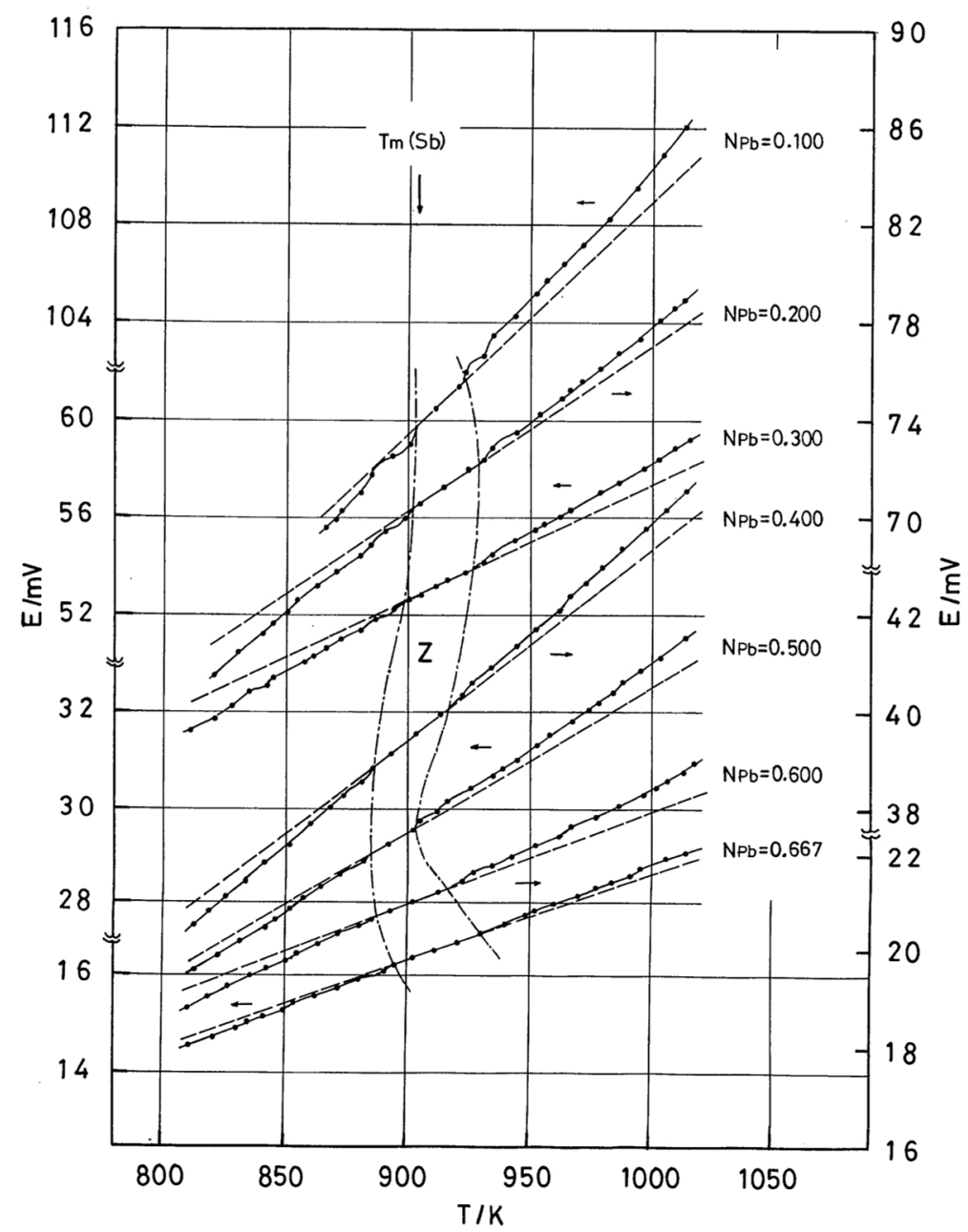

Fig. 4 Relationship between emf and temperature at compositions under $N_{\mathrm{Pb}}=0.667$ of liquid $\mathrm{Pb}$ $\mathrm{Sb}$ alloys. $T_{\mathrm{m}}(\mathrm{Sb})$ : Melting point of antimony, $\mathrm{Z}$ : $\mathrm{E} \mathrm{E}$ zone.

characteristic is helpful in identifying the $\mathrm{E} \mathrm{E}$ zone. The breaks at $N_{\mathrm{Pb}}=0.825$ seem somewhat unclear at first glance though the measurements have sufficient precision for distinguishing them. This would probably be due to the alloy characteristic at the eutectic composition. The zone boundaries were decided with special emphasis on both the data showing pronounced breakings and the zone widths of 20 to $30 \mathrm{~K}$ expected generally. Due to the fact that the zone width has a common characteristic to all the alloys, such distinction becomes easier if the magnitude of its width is considered.

The horizontal portion shown over a limited temperature-composition range at $N_{\mathrm{Pb}}=$ $0.900 \sim 0.950$, seems reliable. As for other evidence concerning such anomaly, there exists a study of the $\mathrm{Zn}-\mathrm{Sn}$ system performed by Scheil et al. ${ }^{(10)}$ It was tentatively made clear that the activities calculated in the $\mathrm{Pb}-\mathrm{Sb}$ alloys tended to flatten out close to the $R$ region as described in the $\mathrm{Pb}-\mathrm{Hg}$ system.

The activities of lead are compared with the values reported in literature ${ }^{(15)}$ in Fig. 6, and indicate good agreement.

The experimental results of the $\mathrm{Zn}-\mathrm{Sb}$ system are shown in Figs. 7 and 8 in which the breaks are more pronounced than in the $\mathrm{Pb}-$ $\mathrm{Sb}$ system. The main reason would probably 


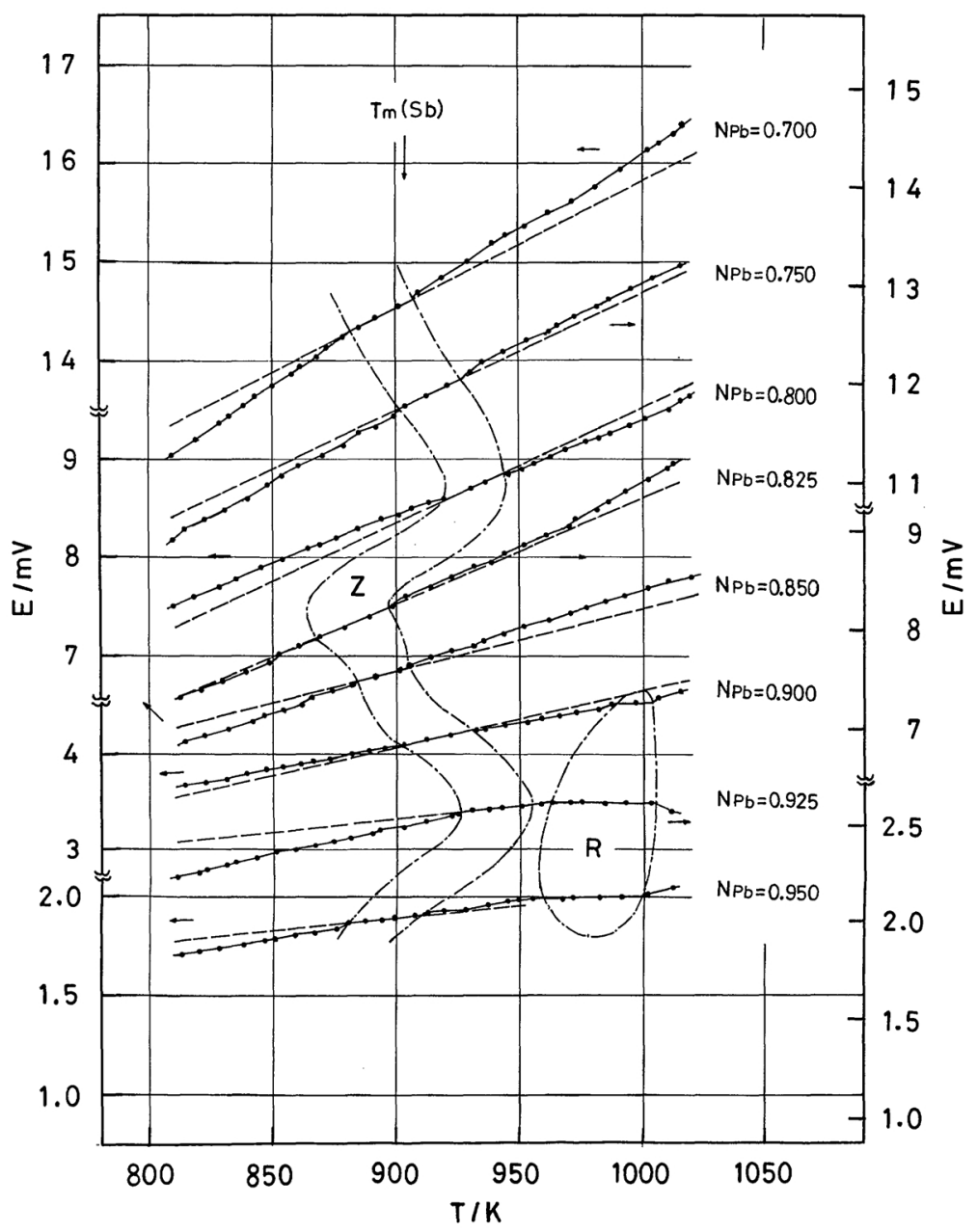

Fig. 5 Relationship between emf and temperature at compositions above $N_{\mathrm{Pb}}=0.700$ of liquid $\mathrm{Pb}$ Sb alloys.

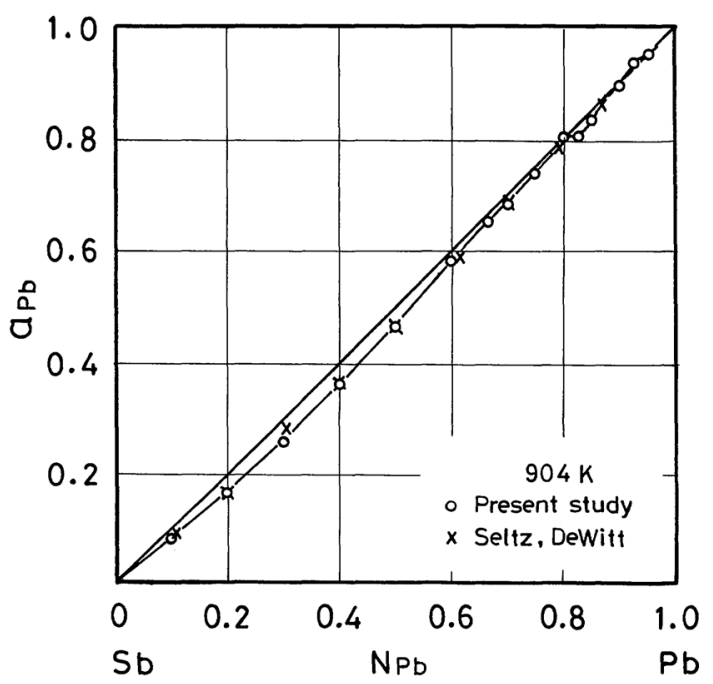

Fig. 6 Activities of component lead in liquid $\mathrm{Pb}-\mathrm{Sb}$ alloys. 


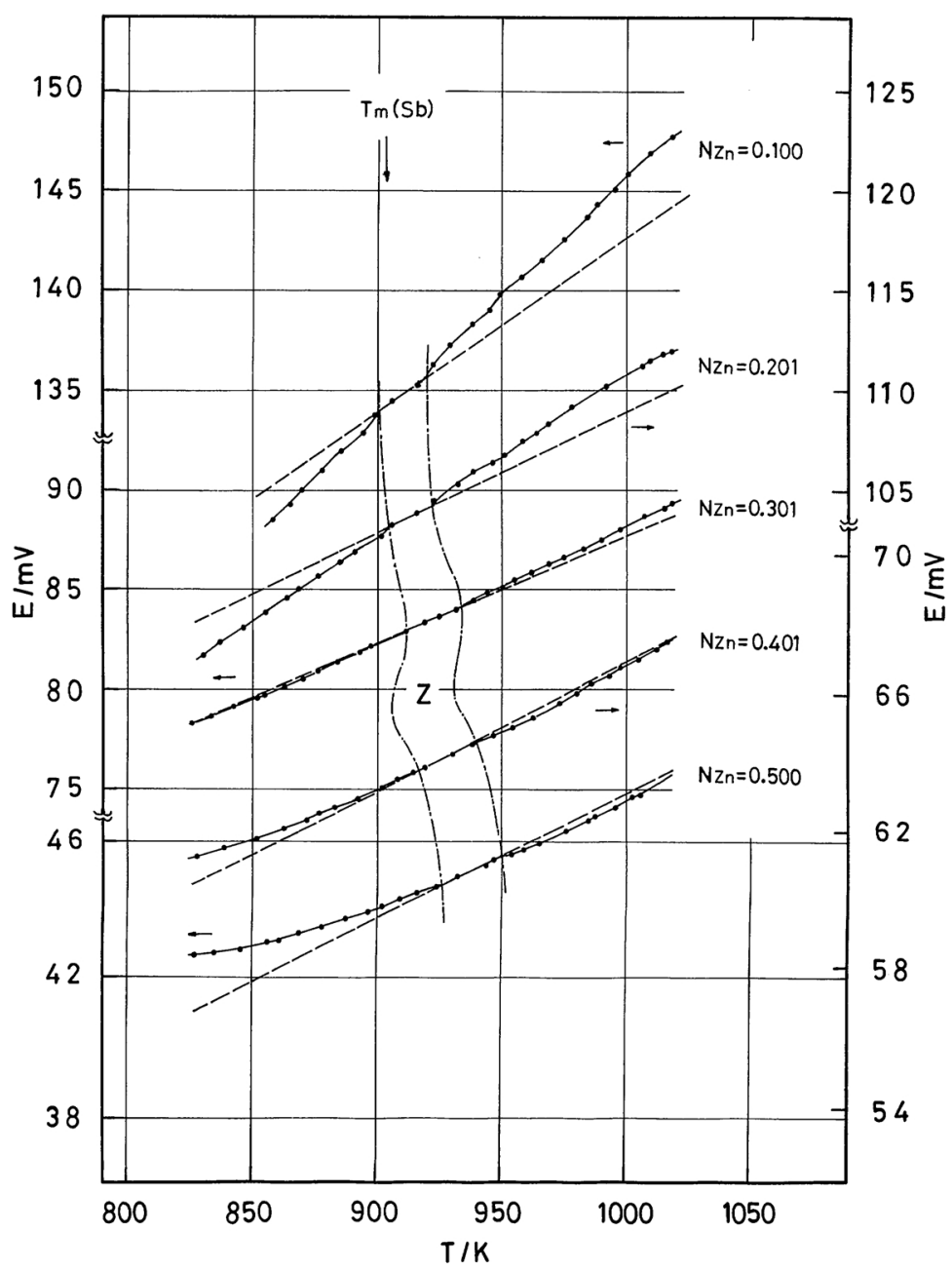

Fig. 7 Relationship between emf and temperature at compositions under $N_{\mathrm{Zn}}=0.500$ of liquid $\mathrm{Zn}-\mathrm{Sb}$ alloys.

be due to the alloy system forming intermetallic compounds. In particular, this anomaly was pronounced at $N_{\mathrm{Zn}}=0.100,0.201$ and 0.800 , but was somewhat unclear at $N_{\mathrm{Zn}}=0.301$, attributable to the eutectic characteristic. It may be assumed that the horizontal region $\mathrm{R}$ would exist over a limited temperature-composition range above $N_{\mathrm{Zn}}=$ 0.900 .

The activities of lead are compared with the values reported in literature ${ }^{(16)(17)}$ in Fig. 9, indicating good agreement. The trend for partial flattening out of the activity curve has frequently been observed ${ }^{(1)(2)(5)}$.

\section{The Relationship between the $\mathbf{E} \mathbf{E}$ Zone and Excess Stability}

There was a similar tendency between the compositional dependence of the $\mathrm{E} \mathrm{E}$ zone and the activity or activity coefficient. However, it was apparent that the best correspondence to the $\mathrm{E} \mathrm{E}$ zone could be obtained by employing the Darken excess stability function ${ }^{(18)}$. When the excess stability is most suitable, the compositional dependence of the activity or activity coefficient must correspond with a slight deviation to that of the $\mathrm{E} \mathrm{E}$ zone. 


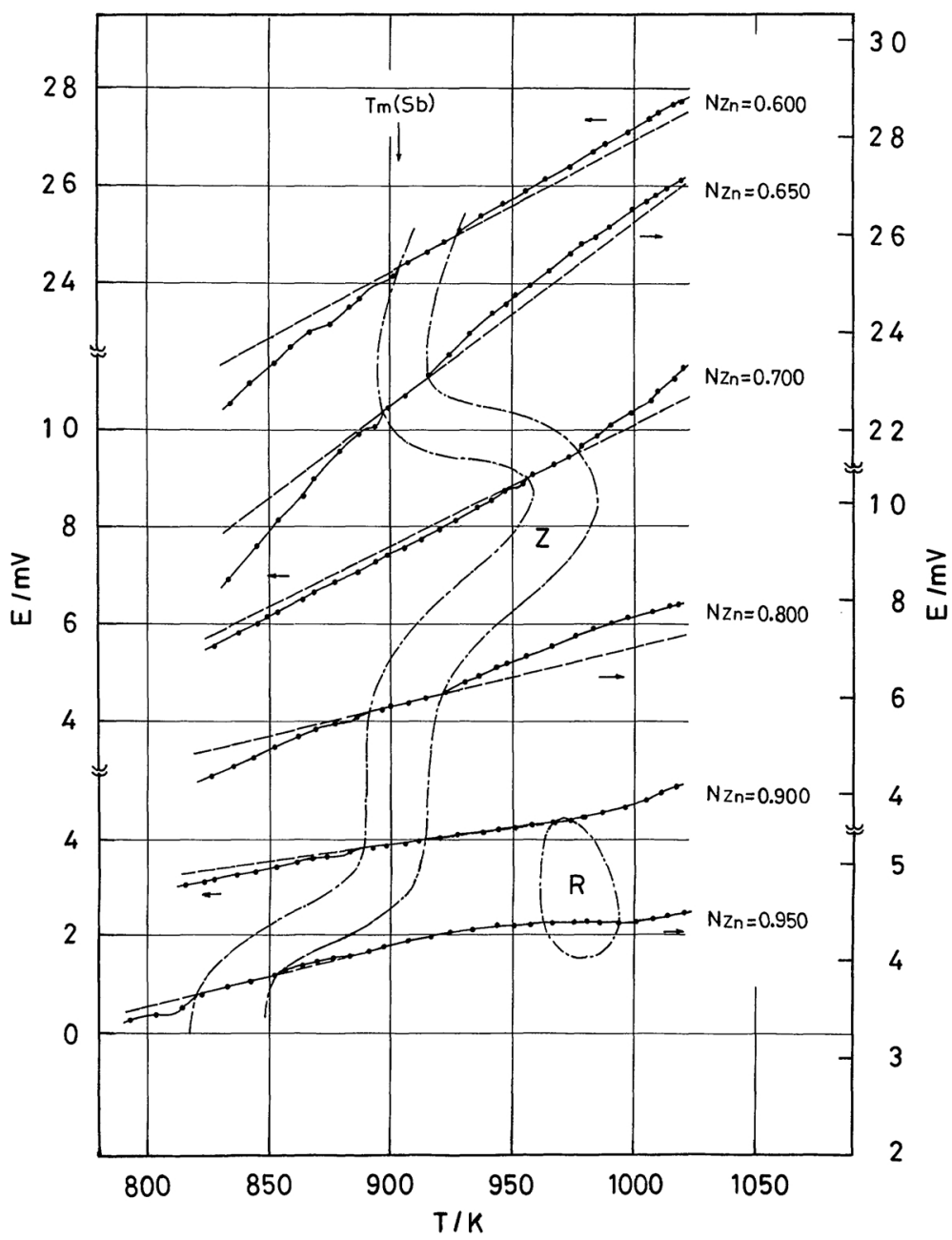

Fig. 8 Relationship between emf and temperature at compositions above $N_{\mathrm{Zn}}=0.600$ of liquid $\mathrm{Zn}-\mathrm{Sb}$ alloys.

The excess stability $\alpha^{\mathrm{E}}$ is given as

$$
\alpha^{\mathrm{E}}=-4.6 R T \operatorname{dlog} \gamma_{i} / \mathrm{d}\left(1-N_{i}\right)^{2}
$$

where $\gamma_{i}$ and $N_{i}$ denote the activity coefficient and the mole fraction of component $i$, respectively. The excess stabilities can be obtained from the activity of each of the two components. However, since the phenomena would be due to the reflection of a property of the component antimony, the values of $\alpha^{\mathrm{E}}$ in the $\mathrm{Pb}-\mathrm{Sb}$ and $\mathrm{Zn}-\mathrm{Sb}$ systems were calculated employing the activity values $a_{\mathrm{Sb}}$ at $904 \mathrm{~K} \mathrm{ob}-$ tained by the Gibbs-Duhem integration. The $\alpha^{\mathrm{E}}$ values of the $\mathrm{Pb}-\mathrm{Hg}$ systems were calculated from the activities $a_{\mathrm{Pb}}$ at $600 \mathrm{~K}$.

Figure 10 shows that the $\alpha^{\mathrm{E}}$ curve calculated for the $\mathrm{Pb}-\mathrm{Sb}$ system is similar in shape to that of the $\mathrm{E} \mathrm{E}$ zone. The Darken function presents a singularity when clustering is expected. It is also evident that there exists a good inverse correspondence between the compositional dependence of the $\mathrm{E} \mathrm{E}$ zone and that of the activity coefficient of antimony.

Figure 11 shows these relations for the $\mathrm{Zn}$ Sb system, indicating that good similarity exists between the compositional dependence of the $\mathrm{E} \mathrm{E}$ zone and $\alpha^{\mathrm{E}}$.

Figure 12 presents the results for the $\mathrm{Pb}-\mathrm{Hg}$ 


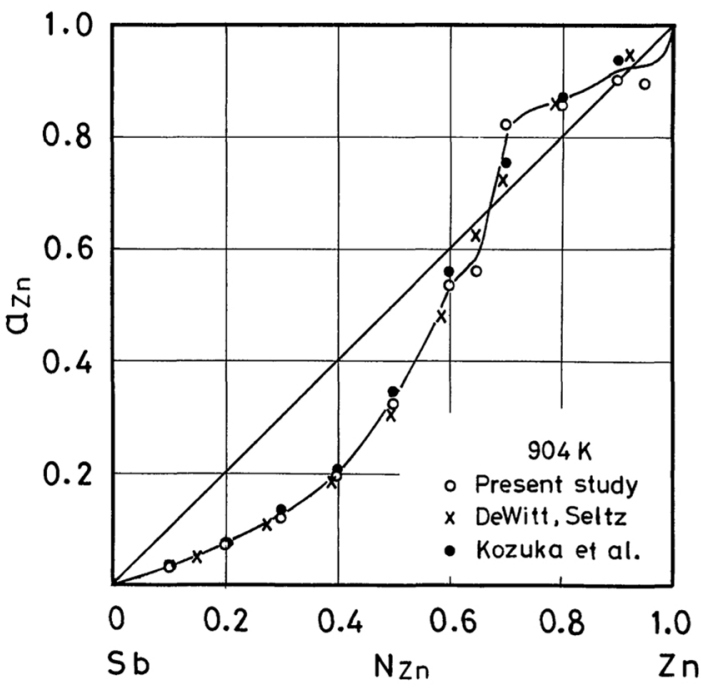

Fig. 9 Activities of component zinc in liquid $\mathrm{Zn}-\mathrm{Sb}$ alloys.

system. The $Z_{1}$ region to be the $\mathrm{E} E$ zone may be assumed to be a reflection of the prefreezing anomaly of pure liquid lead, but the $Z_{2}$ region would probably be due to some property like the intermetallic compound existing in the liquid since the intermetallic compound can separate from the liquid below $415 \mathrm{~K}$ (cf. liquid behavior shown in Fig. 11 in the present study and Fig. 12 in the subsequent paper $^{(6)}$ ) and could be suitably termed the "zone of compound effect". The similarity shown between the $Z_{1}$ and $Z_{2}$ regions is very interesting.

\section{Discussion}

The changes in emf with lapse of time have already been examined previously ${ }^{(2)}$. To decrease its effect as much as possible, the cells in the present study were maintained for $5.4 \mathrm{ks}$ at the starting temperatures as described previously ${ }^{(3)(5)}$.

Since the estimated limits of error in the emf data are $0.05 \sim 0.10 \mathrm{mV}$, even a slight break can be distinguished by means of careful observation.

The present study was carried out with special emphasis on the distinctive anomalies occurring at temperatures close to the freezing point of component metals. Therefore, any irregularity in the relationships over the other

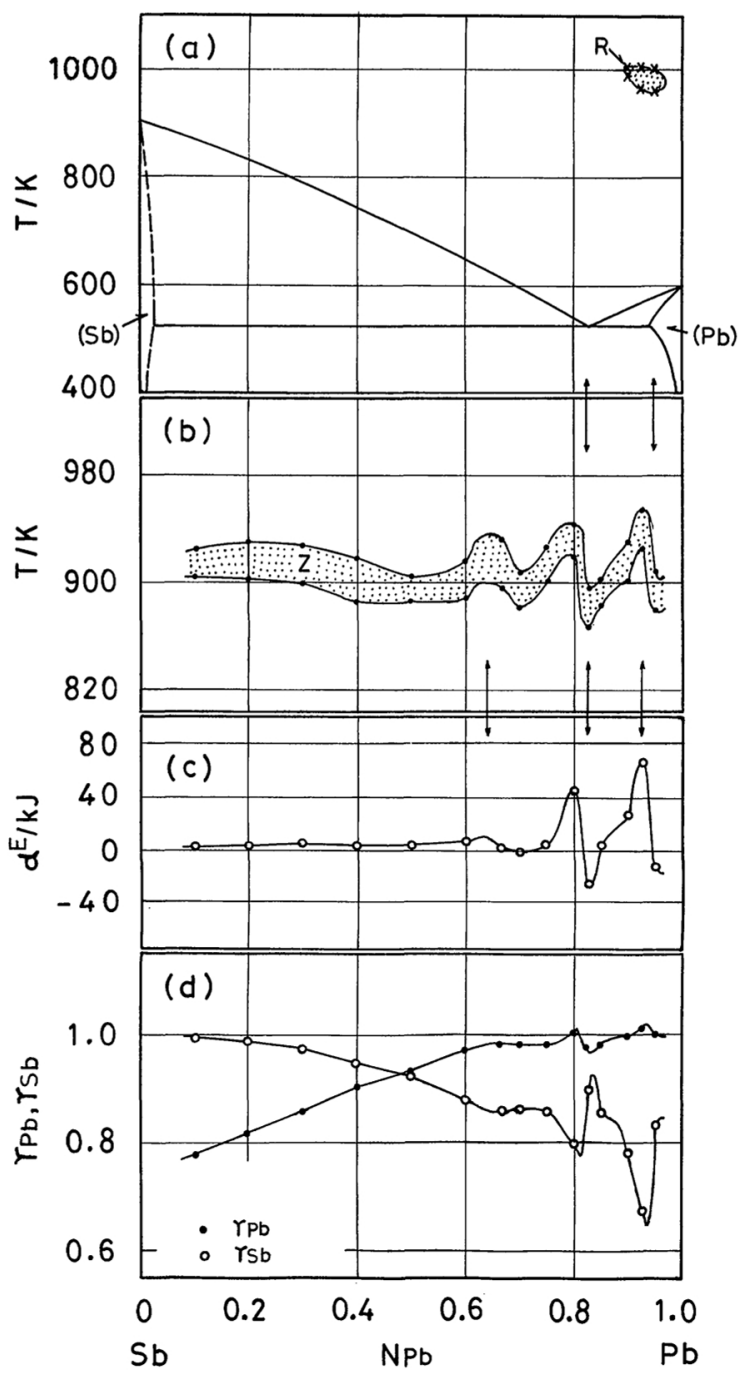

Fig. 10 Comparisons between the E E zone and excess stability, activity coefficients or the phase diagram in the $\mathrm{Pb}-\mathrm{Sb}$ system.

temperature ranges was, in particular, not considered.

The data at the compositions closest to the pure metals, i.e. $N_{\mathrm{Pb}}=0.900$ of Fig. 2 and $N_{i}$ $=0.100$ of Figs. 4 and 7 , suggest that the E E zones of the liquid alloys would exist as a reflection of the pre-freezing anomalies of pure component metals. This will be proved subsequently by density measurements in a separate paper $^{(6)}$.

Filippov $^{(19)}$ has studied the pre-freezing anomalies that occur near the freezing points 


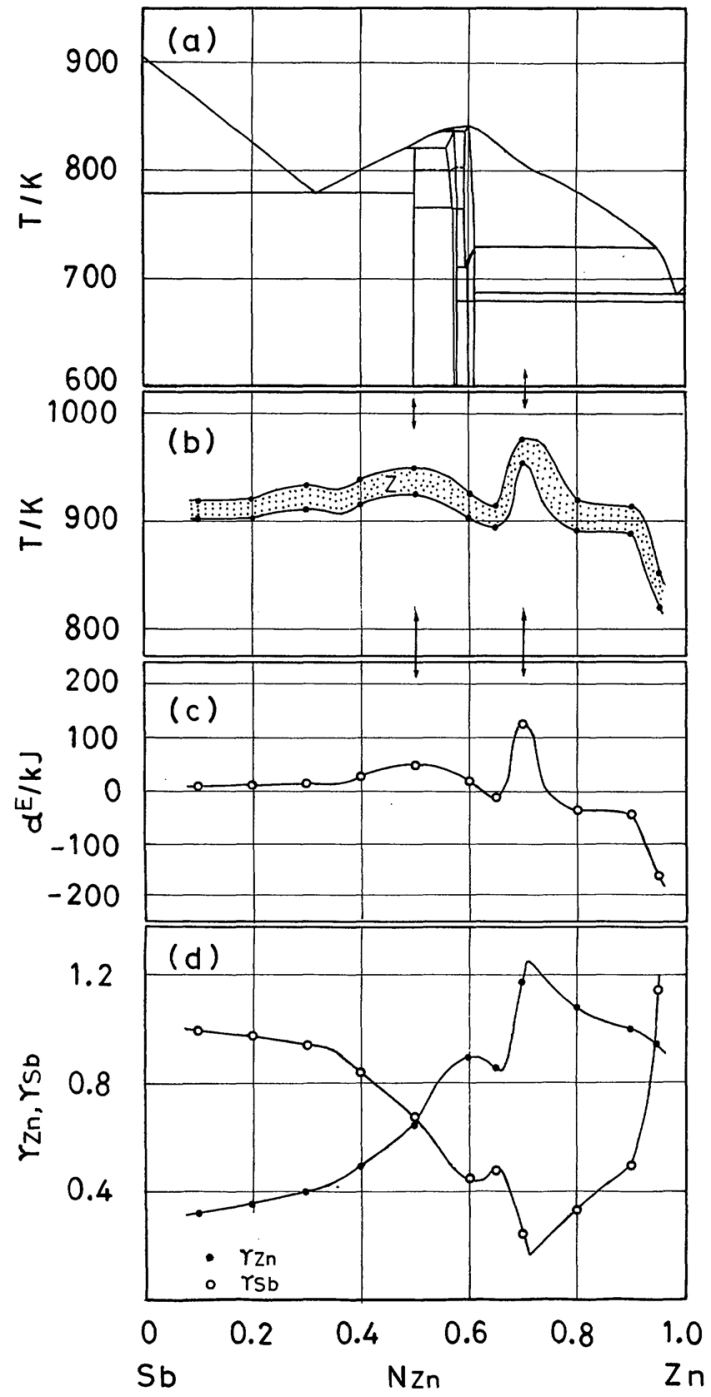

Fig. 11 Comparisons between the E E zone and excess stability, activity coefficients or the phase diagram in the $\mathrm{Zn}-\mathrm{Sb}$ system.

of several metals and proved that the anomalies exist at temperature ranges of about $30 \mathrm{~K}$ width. A similar situation was found in the present study in which the temperature widths of the anomalous range agreed approximately to those of Filippov. Also, "premelting" and "after-melting" (i.e. pre-freezing) effects of pure metals reported previously ${ }^{(20)(21)}$ provide evidence in support of such anomaly. On the other hand, of special interest in this respect is that the liquid crystal of an organic matter ${ }^{(22)}$ also indicates somewhat

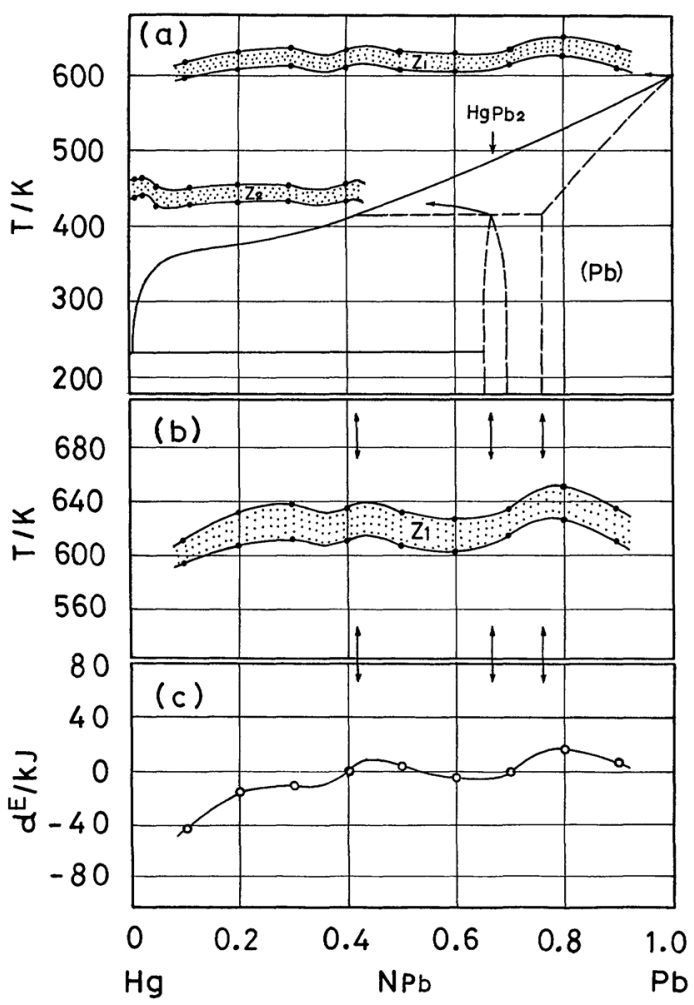

Fig. 12 Comparisons between the $\mathrm{E} \mathrm{E}$ zone and excess stability, or the phase diagram in the $\mathrm{Pb}-\mathrm{Hg}$ system.

similar behavior.

Of a special importance in the present study is the fact that undoubtedly, $\mathrm{E} E$ zones of nearly the same width can exist in the systems considered and that these zones may be related to the excess stabilities.

Since physico-chemical experiments on extraction and refining of metals, in particular in iron and steel making, have been performed mostly at temperatures near the melting points of metals such as iron, the finding that the $\mathrm{E} \mathrm{E}$ zone exists will give a meaningful effect to such experiments. Samarin ${ }^{(23)}$ has indicated that a structural change may occur in liquid $\mathrm{Fe}-\mathrm{C}$ alloys.

Also, a knowledge of these zones will play an important role in arriving at a clearer understanding of the glass forming ability of liquid quench alloys. 


\section{Summary}

The emf-temperature relationships for liquid $\mathrm{Pb}-\mathrm{Hg}$ alloys were obtained by employing the concentration cell. Anomalous behavior with distinct breaks at two different temperatures close to the freezing point of lead was observed. The temperature ranges between the two breaks were termed "E $\mathrm{E}$ zones". A similar situation was found in $\mathrm{Pb}-\mathrm{Sb}$ and $\mathrm{Zn}$ $\mathrm{Sb}$ alloys.

It may be assumed that the $\mathrm{E} \mathrm{E}$ zones are a reflection of the pre-freezing anomalies of pure liquid metals.

It was made clear that the compositional dependence of the $\mathrm{E} \mathrm{E}$ zone approximately correlates with that of activity coefficients and more rigidly to excess stabilities.

\section{REFERENCES}

(1) K. Okajima and H. Sakao: Trans. JIM, 16 (1975), 95.

(2) K. Okajima and H. Sakao: Trans. JIM, 19 (1978), 92.

(3) K. Okajima and H. Sakao: Trans. JIM, 22 (1980), 226.

(4) K. Okajima and H. Sakao: Trans. JIM, 24 (1983), 216.

(5) K. Okajima, S. Matsubuchi and H. Sakao: Trans. JIM, 26 (1985), 183.

(6) K. Okajima and H. Sakao: Trans. JIM, 29 (1988), 469.

(7) K. Yamada, N. Koura and N. Yoneda: J. Min. Met. Inst. Japan, 93 (1977) , 507.

(8) R. Hultgren, P. D. Desai, D. T. Hawkins, M. Gleiser and K. K. Kelley: Selected Values of the Ther- modynamic Properties of Binary Alloys, ASM, Metals Park, Ohio, (1973), p. 970.

(9) O. Kubaschewski and C. B. Alcock: Metallurgical Thermochemistry, Pergamon Press, Oxford, (1979), pp. 332, 338.

(10) E. Scheil and E. D. Müller: Z. Metallk., 53 (1962), 389.

(11) M. Hansen and K. Anderko: Constitution of Binary Alloys, McGraw-Hill, New York, (1958), pp. $1 \sim 1257$.

(12) R. P. Elliott: Constitution of Binary Alloys, First Suppl., McGraw-Hill, New York, (1965), pp. 1 867.

(13) F. A. Shunk: Constitution of Binary Alloys, Second Suppl., McGraw-Hill, New York, (1969), pp. 1 711.

(14) H. A. Laitnen and C. H. Liu: J. Amer. Chem. Soc., 80 (1958), 1015.

(15) H. Seltz and B. J. DeWitt: J. Amer. Chem. Soc., 61 (1939), 2594.

(16) B. J. DeWitt and H. Seltz: J. Amer. Chem. Soc., 61 (1939), 3170.

(17) Z. Kozuka, J. Moriyama and I. Kushima: J. Electrochem. Soc. Japan, 29 (1961), 104.

(18) L. S. Darken: Trans. Met. Soc. AIME, 239 (1967), 80.

(19) E. S. Filippov: Izv. V. U. Z. Chernaya Metall., (1975), (7), 119.

(20) Japan Inst. Metals: Structure and Physical Property of Liquid Metals, Japan Inst. Metals, Sendai, (1971), p. 136.

(21) J. K. Kristensen and R. M. J. Cotterill: Phil. Mag., 36 (1977), 437.

(22) T. Tachibana, K. Kobayashi, S. Kusabayashi, H. Suzuki, K. Honda and M. Sukigara: Liquid Crystal, Kyoritsu Shuppan, Tokyo, (1972), p. 3.

(23) A. Samarin: Joint Symposium of USSR and Japan on Physical Chemistry of Metallurgical Processes, Moscow, (1967) (Proc. Conf. edited by Iron Steel Inst. Japan, Tokyo, 1967, p. 90). 